\title{
Inclusion and marginalization of learners in primary education (Finland)
}

\author{
Huilla, Heidi
}

Bloomsbury Publishing

2020

Huilla , H \& Kosunen , S 2020 , Inclusion and marginalization of learners in primary education (Finland) . in J Kauko, M T Tatto \& I Menter (eds), Bloomsbury education and childhood studies : Articles . Bloomsbury Publishing , London . https://doi.org/10.5040/9781350996496.0002

http://hdl.handle.net/10138/334928

https://doi.org/10.5040/9781350996496.0002

unspecified

acceptedVersion

Downloaded from Helda, University of Helsinki institutional repository.

This is an electronic reprint of the original article.

This reprint may differ from the original in pagination and typographic detail.

Please cite the original version. 


\begin{tabular}{|l|l|}
\hline Article title & $\begin{array}{l}\text { INCLUSION AND MARGINALISATION OF LEARNERS in Primary Education } \\
\text { (Finland) }\end{array}$ \\
\hline Author 1 & Heidi Huilla \\
\hline $\begin{array}{l}\text { Author 1 } \\
\text { affiliation }\end{array}$ & Heidi Huilla is PhD Researcher at the University of Helsinki, Finland \\
\hline Author 2 & Sonja Kosunen \\
\hline $\begin{array}{l}\text { Author 2 } \\
\text { affiliation }\end{array}$ & Sonja Kosunen is Assistant Professor at the University of Helsinki, Finland \\
\hline Regional Editor & Jaakko Kauko \\
\hline Editor in Chief & Professor lan Menter and Professor Maria Teresa Tatto \\
\hline
\end{tabular}

\section{Keywords}

Minorities, ethnicity, gender, social class, special needs education

\section{Glossary terms}

Statutory government transfer: A system for sharing costs between the state and the municipalities, aimed at minimising the differences between municipalities in terms of income and cost levels, and their needs for services, based on their demographics.

National core curriculum: The instrument through which the Finnish National Agency for Education sets out binding educational guidelines on the national level. All providers of education, commonly the municipalities, base their own curricula on the national curriculum, and every school prepares its own guidelines for learning in accordance with the municipal plan.

General, intensified, and special support: All children have the right to general support, which comprises all the guidance and support given to pupils in the everyday life of a school. Intensified support should be available to those who are in need of support on a regular basis, or require various forms of support at the same time. Such support is given in mainstream or special classes. Pupils for whom general and intensified support are inadequate receive special support, meaning broadly based and systematic support in separate specialised teaching groups, although they may also be taught in mainstream education. 
Emphasized classes: These selective classes in comprehensive school emphasize a specific subject area such as mathematics, music or the arts. Schools may give aptitude tests in the subject matter in question as a selection mechanism. In practice, most selected pupils study all subjects in their own, separate classes. The emphasized subject is allocated between one and two hours more teaching time on a weekly basis.

Multi-professional welfare support: Both intensified and special pupil support require evaluation and organization from a multi-professional group. Multi-professionalism means involving not only teachers and principals but also those engaged in school health or psychological care as well as the school social worker. Support for learning may be supplemented with respective pastoral support. Support in the form of psychological or social evaluation requires consent from the family whereas support for learning does not.

\section{Research on inclusion and marginalization}

Inclusion is often identified as a principle purporting to identify and prevent barriers to participation and success not merely in education but in the whole life course and society in general. Its definition can be broad, covering the whole life course of a pupil, for example, and including access to as well as participation and success in education (see Ainscow, Booth and Dyson 2006; Lakkala 2008; SeppäläPänkäläinen 2009; Louhela 2012). Most of the empirical research on inclusion in primary education conducted in Finland during the past decade concerns pupils with learning difficulties, and is positioned in the field of special education (see e.g. Eskelä-Haapanen 2012; Jokinen 2012; Teräväinen 2011). Here, we understand inclusion in its broader sense as applying to pupils from different social, ethnic and linguistic backgrounds, regardless of gender, those with different educational needs and disabilities, and pupils belonging to different societal minorities (see also Peltola, Niemi \& Kosunen in this book). Researchers have recently reported the emergence of different social and ethnic divisions in Finland, especially in terms of school segregation in urban areas (see Bernelius 2013; Kosunen et al. 2016; 
Seppänen et al. 2015). The selection-based division of emphasized classes, general (local schoolcatchment area) classes, and special classes has been debated in research literature (Simola et al. 2015). The divisions are not restricted to social class, but are also manifested as gendered choices and differentiation based on school success in comprehensive education (Berisha \& Seppänen 2015). Geographical differentiation between urban and rural areas is also noted (Jakku-Sihvonen \& Komulainen 2004).

We see marginalization as contributing to the general understanding of inclusion, not as its counterpart. It is a question of who is normalized in the discourse, policy and practice, and thereby of who are considered 'the others' (e.g. Riitaoja 2013; also Lempinen 2018; Mietola 2014) and thereby excluded from the sphere of normality.

\section{Demographics}

Primary education in Finland is mandatory for all 7-13-year-olds and is organized in the vast majority (about 97\%) of cases in state-funded (public) schools.

Finland has altogether 5.5 million inhabitants, including the indigenous Sami population and several other long-established language and religious minorities. Largest minority groups by language are Russian and Estonian and by religion Jehova's witnesses and Islam communities. According to Statistics Finland in 2014 less than $6 \%$ of the population had a foreign background. (Saukkonen 2016.) Many of the minorities have a vulnerable position in the Finnish education system (Souto 2011; Vettenranta et al. 2016; Helakorpi, Lappalainen \& Mietola 2018; Rahko-Ravantti 2016).

A linguistic division pervades the Finnish education system: the two official native languages, Finnish and Swedish (5.5\% of the population) have their own institutions ranging from early childhood to higher education, although the same national core curriculum is followed in both. This parallel system causes 
spatial separation (From \& Sahlström 2017) as Finnish-speaking and Swedish-speaking children are taught separately in monolingual schools (Sahlström, From, \& Slotte-Lüttge 2013).

Finland's national Churches are the Lutheran (about $70 \%$ of the population) and the Orthodox (about 1\%). Nationally, approximately 90 per cent of pupils attend lessons in Lutheran religious education. (Kallioniemi \& Ubani 2016; BEA 454/2003 13§.)

\section{Policies and laws}

The Finnish system of comprehensive schooling was introduced in the 1970s to provide one school for all, as was the practice in the Nordic countries more generally (Antikainen 2006). The reform was designed to increase equality and challenge the system level marginalization and exclusion the parallel educational system maintained (Ahonen 2003). The practice of ability grouping within the school was also abolished in 1985, thereby making the comprehensive school fairly uniform, at least officially, until the 1990s. The concept of school choice was introduced in the Basic Education Act of 1998 (Seppänen 2006), and this resulted in the emergence of public school markets.

Municipalities with the authority to levy taxes are responsible for providing education in Finland. However, there is a system of statutory government transfer for those faced with conditions regarded as special that require additional funding. Such issues include morbidity, unemployment, the prevalence of foreign languages, bilingualism (Finnish and Swedish), the Sami language, insularity, population density, and educational background (Finlex 1704/2009; Finlex 676/2014; Jakku-Sihvonen \& Kuusela 2012). Municipalities themselves have diverse support systems for schools that are considered in need of more resources, such as needs-based resource funding (so-called positive-discrimination funding) policy in the capital, Helsinki. Schools in neighborhoods in which educational and income levels are relatively low, and a high proportion of the population are native speakers of foreign languages are allocated more funding. (see Bernelius 2013; Silliman 2017.) 
The most recent and significant reform affecting inclusive political practices was introduced in 2010, changing the ways in which special support is defined and introduced to pupils. Under the reform preventive practices are emphasized, the language used is pedagogical rather than medical, and there is a regulatory move to a three-tiered (general, intensified and special) support system in which the support intensifies on successive tiers (see Ahtiainen 2017; Lempinen 2016; BEA 628/1998; BEA 642/2010). The role of separate special-education classes changed, as more and more support was targeted on provision within general education in regular school classes. The reform is in line with the conventions and agreements to which Finland has committed (e.g. UNESCO 1994; UN 1989).

Pupils with a migrant background who do not speak Finnish can be supported by instruction preparing. The aim is to teach pupils the language and other skills required in mainstream education and also in the wider society. Nine hundred hours are allocated to instruction preparing, organized in separate teaching groups from which pupils integrate to mainstream lessons according to their individual learning plans. The form and execution of preparatory education is not, however, binding on the national level. (BEA 628/1998; FNAE 2015.)

The right of different groups to maintain and develop their language was written into the Finnish constitution in 2000, Roma and Sami being mentioned as examples (Helakorpi, Lappalainen \& Mietola 2018; CF 731/1999 §17). According to the law, all minority languages have the statutory right to government transfer payments for additional teaching in their language for 2.5 hours per week (Ministry of Education 248/1995). However, most of the teaching of the Sami in their home regions in northern Finland should be in Sami (BEA 628/1998 §10). This right is mostly realized in primary education (Rahko-Ravantti 2016).

Religious education is given in accordance with the pupil's own religion, based on the guidelines of the national core curriculum and organized in public schools, and the teaching is provided in separate learning groups accordingly. Christianity is the only religion that is taught on the denominational levels, other religions are not. Providers of education are also obliged to organize secular ethics education for 
those who are not members of a religious community. (Kallioniemi \& Ubani 2016; Sakaranaho 2013; Zilliacus 2014; BEA 454/2003 13§.)

\section{Inequality}

The basic principle in Finnish comprehensive education is one school for all. Education is, in principle, inclusive per se.

Research on sexuality at primary level is scarce. It is shown, however, that many practices and interactions in schools strengthen the prevailing discourse of heteronormativity and dichotomous gender division. An important step for sexual minorities has been the national core curriculum from 2014, which explicitly prohibits discrimination based on sexual orientation and handles gender diversity. (Heikkinen \& Huuki 2005; Kjaran \& Lehtonen 2017.)

There is a widening gap between girls and boys in terms of primary-school achievement (see e.g. Vettenranta et al. 2016), which has aroused discussion about how structures of schooling meet the needs of boys. However, researchers have also pointed out problems related to gendered and dichotomous understanding of pupils (e.g. Lunabba 2018). There is also a difference in achievement between pupils with an affluent as opposed to a more disadvantaged background: the more advantageous the educational background of the parents, the better are the results achieved in mathematics and the natural sciences. (Vettenranta et al. 2016.)

Pupils with a migrant background are in a vulnerable position in many school sectors. Experiences of loneliness, racism and discrimination are common, for example. These pupils tend to achieve worse outcomes than native Finnish speakers in international assessments, but they do better than in many other contexts. (Halme et al. 2017; Souto 2011; Vettenranta et al. 2016.) Despite the special status related to language, the estimated 9,000-10,000 Finnish Roma living in Finland are disadvantaged in terms of education (see Helakorpi, Lappalainen \& Mietola 2018). 
Pupils who receive intensified or special support may be placed in general classes instead of separate special classes. This is not mandatory, however, hence there are varying practices regarding the placement of the 16.8 per cent (in 2017) of pupils receiving intensified (9.8\%) or special (7.0\%) support (BEA 642/2010; Statistics Finland 2017; Ahtiainen 2017; also Simola et al. 2015; Pulkkinen \& Jahnukainen 2015). Severe disabled pupils tend to be placed and to be taught separately (Pirttimaa et al. 2015; Niemi, Mietola \& Helakorpi 2010).

\section{Assistance and resources:}

There are also other systemic policies and practices that strongly support its equalizing role, including the provision of school meals, healthcare and dental services to all pupils. The materials used in schools are free, as is transportation for those living further away. Many staff members work alongside classroom teachers to support learning and pastoral needs, including teachers of Finnish as a second language, additional teaching staff, and assistants. Multi-professional welfare support for pupils is complimentary. (BEA 628/1998; Finlex 1287/2013.)

\section{Further reading and online resources}

Finnish National Agency for Education, (2017), Finnish education in a nutshell. https://www.oph.fi/download/146428_Finnish_Education_in_a_Nutshell.pdf

Kosunen, S. (2016), Families and the social space of school choice in urban Finland, Helsinki: University of Helsinki.

Honkasilta, J., Ahtiainen, R., Hienonen, N. and Jahnukainen, M. (Forthcoming), Inclusive and Special Education and the Question of Equity in Education: The Case of Finland, in Schuelka, M., Johnstone, C., Thomas, G. and Artiles, A. (eds) The SAGE Handbook on Inclusion and Diversity in Education, CA: Thousand Oaks.

Lahelma, E. (2014), Troubling discourses on gender and education, Educational Research, 56(2): $171-183$.

Riitaoja, A. Layne, H., Liu, H., Paavola, H., Kralovec, E. and Orozco, R. (2015), Constructing Norms and Silences on Diversities Through the Spaces in Three Schools in Helsinki Region in Finland, World Studies in Education, 16(2), pp. 19-32. 


\section{References}

Ahonen, S. (2003), Yhteinen koulu: Tasa-arvoa vai tasapäisyyttä? Koulutuksellinen tasa-arvo Suomessa Snellmanista tähän päivään, Tampere: Vastapaino.

Ahtiainen, R. (2017). Shades of change in Fullan's and Hargreaves's models: Theoretical change perspectives regarding Finnish special education reform. Helsinki: University of Helsinki.

Ahtiainen , R., Lintuvuori, M., Hienonen, N., Jahnukainen, M. and Hautamäki, J. (2017), Erityisten nimeäminen ja käsitteet perusopetuksessa - lyhyt historia ja nykytila, in Toom, A., Rautiainen, M. and Tähtinen, J. (eds), Toiveet ja todellisuus: Kasvatus osallisuutta ja oppimista rakentamassa, Kasvatusalan tutkimuksia, Nro 75, Turku: Suomen kasvatustieteellinen seura, 119-142.

Ainscow, M., Booth, T. and Dyson, A. (2006), Improving schools, developing inclusion, London: Routledge.

Antikainen, A. (2006), In search of the Nordic model in education. Scandinavian journal of educational research, 50(3): 229-243.

BEA 628/1998, Basic Education Act. https://www.finlex.fi/fi/laki/ajantasa/1998/19980628 [accessed 16 April 2019].

BEA 454/2003, Basic Education Act. https://www.finlex.fi/fi/laki/ajantasa/1998/19980628 [accessed 16 April 2019].

BEA 642/2010, Basic Education Act. https://www.finlex.fi/fi/laki/ajantasa/1998/19980628 [accessed 16 April 2019].

Berisha, A.- K. and Seppänen, P. (2017), Pupil Selection Segments Urban Comprehensive Schooling in Finland: Composition of School Classes in Pupils' School Performance, Gender, and Ethnicity, Scandinavian Journal of Educational Research, 61(2): 240-254.

Bernelius, V. (2013), Eriytyvät kaupunkikoulut. Helsingin peruskoulujen oppilaspohjan erot, perheiden kouluvalinnat ja oppimistuloksiin liittyvät aluevaikutukset osana kaupungin eriytymiskehitystä, Helsinki City Urban Facts Research Publications 2013:1.

CF 731/1999, The Constitution of Finland. https://www.finlex.fi/fi/laki/ajantasa/1999/19990731 [accessed 16 April 2019].

Eskelä-Haapanen, S. (2012), Kohdennettu tuki perusopetuksen alkuluokilla, Tampere: Tampere University Press.

Finlex 1704/2009, Laki kunnan peruspalvelujen valtionosuudesta. https://www.finlex.fi/fi/laki/ajantasa/2009/20091704 [accessed 16 April 2019].

Finlex 676/2014, Laki kunnan peruspalvelujen valtionosuudesta annetun lain muuttamisesta. https://www.finlex.fi/fi/laki/alkup/2014/20140676\#Pidp447141424 [accessed 16 April 2019].

Finlex 1287/2013: $\quad$ Oppilas- $\quad$ ja $\quad$ opiskelijahuoltolaki https://www.finlex.fi/fi/laki/ajantasa/2013/20131287\#L1P7 [accessed 16 April 2019]. 
From, T. and Sahlström, F. (2017), Shared Places, Separate Spaces: Constructing Cultural Spaces through Two National Languages in Finland, Scandinavian Journal of Educational Research, 61(4): 465-478. DOI: 10.1080/00313831.2016.1147074

Halme, N., Hedman L., Ikonen, R. and Rajala, R. (2017), TYÖPAPERI 15/2018, Lasten ja nuorten hyvinvointi 2017, THL: Kouluterveyskyselyn tuloksia. http://www.julkari.fi/handle/10024/136748 [accessed 23 April 2019].

Heikkinen M \& Huuki T (2005) Hoiva, huolenpito ja elollisesta huolehtiminen koulun sukupuolistavina piiloisina sisältöinä. In: Teräs, L (ed) Koulutus, sukupuolisosialisaatio ja teknologia - näkökulmia segregaatioon. Kajaani, Kainuun sanomain kirjapaino, 17-30.

Helakorpi, J., Lappalainen, S. and Mietola, R. (2018), Equality in the Making? Roma and Traveller Minority Policies and Basic Education in Three Nordic Countries, Scandinavian Journal of Educational Research, DOI: 10.1080/00313831.2018.1485735

Jakku-Sihvonen, R. and Komulainen, E. (2004), Alueellinen ja koulujen välinen vaihtelu perusopetuksen oppimistuloksissa, Kasvatus, 35 (3): 272-285.

Jakku-Sihvonen, R. and Kuusela, J. (2012), Perusopetuksen aika: Selvitys koulujen toimintaympäristöä kuvaavista indikaattoreista, Opetus- ja kulttuuriministeriön työryhmämuistioita ja selvityksiä, 2012:13.

Jokinen, K. (2012), Opintie pienluokan kautta: Peruskoulun alkuopetuksen pienluokkatoiminnan arviointia, Kokkola: Jyväskylän yliopisto, Kokkolan yliopistokeskus Chydenius.

Kallioniemi, A. and Ubani, M. (2016), Religious education in Finnish School system, in Niemi, H., Toom, A. and Kallioniemi, A. (eds.), Miracle of Education, The Principles and Practices of Teaching and Learning in Finnish Schools, Sense Publishers: Rotterdam/Boston,Taipei, 179-190.

Kjaran, J. I. and Lehtonen, J. (2018), Windows of opportunities: Nordic perspectives on sexual diversity in education. International Journal of Inclusive Education, 22(10): 1035-1047, DOI: $10.1080 / 13603116.2017 .1414319$

Kosunen, S., Bernelius, V., Seppänen, P., and Porkka, M. (2016), School choice to lower secondary schools and mechanisms of segregation in Urban Finland. Urban Education, 0042085916666933.

Lakkala, S. (2008), Inklusiivinen opettajuus: Toimintatutkimus opettajankoulutuksessa, Rovaniemi: University of Lapland.

Lempinen, S. (2018), Parental and municipal school choice in the case of children receiving support, Turun yliopiston julkaisuja.

Louhela, V. (2012), Kuulluksi tulemisen pedagogiikka kaikille yhteisessä koululiikunnassa, Oulu: University of Oulu.

Lunabba, H. (2018), Laadullisen tutkimuksen näkökulma poikien koulu- ja hyvinvointikeskusteluun, in Kivijärvi, A., Huuki, T. and Lunabba, H. (eds), Poikatutkimus, Tampere: Vastapaino, 103-120.

Mietola, R. (2014), Hankala erityisyys: Etnografinen tutkimus erityisopetuksen käytännöistä ja erityisyyden muotoutumisesta yläkoulun arjessa, Helsinki: University of Helsinki.

Ministry of Education 248/1995, Opetusministeriön päätös maahanmuuttajien sekä saamenkielisten, romanikielisten ja vieraskielisten oppilaiden täydentävään opetukseen peruskoulussa ja lukiossa 
myönnettävän valtionavustuksen perusteista. $\underline{\text { https://www.finlex.fi/fi/laki/alkup/1995/19950248 }}$ [accessed 23 April 2019].

FNAE, Finnish National Agency for Education, (2015), Perusopetukseen valmistavan opetuksen opetussuunnitelman perusteet 2015, Määräykset ja ohjeet 2015:49.

Niemi, A., Helakorpi, J. and Mietola, R. (2010), Erityisluokka elämänkulussa: Selvitys peruskoulussa erityisluokalla opiskelleiden vammaisten, romaniväestöön kuuluvien ja maahanmuuttajataustaisten nuorten aikuisten koulutus- ja työelämäkokemuksista, Helsinki: Sisäasiainministeriö.

Pirttimaa, R., Räty, L., Kokko, T. and Kontu, E. (2015), Vaikeimmin kehitysvammaisten lasten opetus ennen ja nyt, In Jahnukainen, M., Kontu, E, Thuneberg, H. and Vainikainen, M-P. (Eds), Erityisopetuksesta oppimisen ja koulunkäynnin tukeen., Studies in education 67, Turku: Finnish Educational Research Association.

Pulkkinen and Jahnukainen, M. (2015), Erityisopetuksen järjestäminen ja resurssit kunnissa lakimuutosten jälkeen, In Jahnukainen, M., Kontu, E, Thuneberg, H. and Vainikainen, M-P. (Eds), Erityisopetuksesta oppimisen ja koulunkäynnin tukeen, Studies in education 67. Turku: Finnish Educational Research Association.

Rahko-Ravantti, R. (2016), Saamelaisopetus Suomessa: Tutkimus saamelaisopettajien opetustyöstä suomalaiskouluissa, Rovaniemi: University of Lapland.

Riitaoja, A. (2013), Toiseuksien rakentuminen koulussa: Tutkimus opetussuunnitelmista ja kahden helsinkiläisen alakoulun arjesta, Helsinki: University of Helsinki.

Sahlström, F., From, T., and Slotte-Lüttge, A. (2013), Två skolor och två språk under samma tak, In L. Tainio and H. Harju-Luukkainen (Eds), Kaksikielinen koulu - tulevaisuuden monikielinen Suomi, Jyväskylä: Finnish Educational Research Association.

Sakaranaho, T. (2013), Religious Education in Finland, Temenos - Nordic Journal of Comparative Religion, 49(2), 225-254. Retrieved from https://journal.fi/temenos/article/view/9547 [accessed 16 April 2019].

Saukkonen, P. (2016) Monikulttuurisuuden tilastointi kaipaa uudistamista. Tilastokeskus. http://www.stat.fi/tietotrendit/artikkelit/2016/monikulttuurisuuden-tilastointi-kaipaa-uudistamista/ Accessed 30.8.2019.

Seppälä-Pänkäläinen, T. (2009), Oppijoiden moninaisuuden kohtaaminen suomalaisessa lähikoulussa: Etnografia kouluyhteisön aikuisten yhdessä oppimisen haasteista ja mahdollisuuksista, Jyväskylä: University of Jyväskylä.

Seppänen, P. (2006), Kouluvalintapolitiikka perusopetuksessa: Suomalaiskaupunkien koulumarkkinat kansainvälisessä valossa, Turku: Suomen kasvatustieteellinen seura.

Seppänen, P., Kalalahti, M., Rinne, R. and Simola, H. (eds), (2015), Lohkoutuva peruskoulu Perheiden kouluvalinnat, yhteiskuntaluokat ja koulutuspolitiikka, Research in Education Sciences 68. Jyväskylä: Finnish Educational Research Association.

Silliman, M. I. (2017), Targeted funding, immigrant background and educational outcomes: Evidence from Helsinki’s "Positive Discrimination Policy, VATT Working Papers 91. 
Simola, H., Seppänen, P., Kosunen, S. and Vartiainen, H. (2015), Perusopetuksen valikoitumisen reitit suomalaiskaupungeissa, In Seppänen, P., Kalalahti, M., Rinne, R. and Simola, H. (eds), Lohkoutuva peruskoulu Perheiden kouluvalinnat, yhteiskuntaluokat ja koulutuspolitiikka, Research in Education Sciences 68. Jyväskylä: Finnish Educational Research Association.

Souto, A. (2011), Arkipäivän rasismi koulussa: Etnografinen tutkimus suomalais- ja maahanmuuttajanuorten ryhmäsuhteista, Helsinki: Nuorisotutkimusseura: Nuorisotutkimusverkosto.

Statistic Finland (2017). Appendix table 1. Comprehensive school pupils having received intensified or special support. https://www.stat.fi/til/erop/2017/erop 2017 2018-06-11 tau 001 fi.html [accessed 23 April 2019].

Teräväinen, V. (2011), Asperger-erityisoppilaan sosiaalinen integraatio, Tampere: Tampere University Press.

UN (United Nations), (1989), Convention on the Rights of the Child.

UNESCO, (1994), The Salamanca statement and framework for action on special needs education.

Vettenranta, J., Hiltunen, J., Nissinen, K., Puhakka, E., and Rautopuro, J. (2016), Lapsuudesta eväät oppimiseen, Neljännen luokan oppilaiden matematiikan ja luonnontieteiden osaaminen, Kansainvälinen TIMSS-tutkimus Suomessa, Jyväskylän yliopisto, Koulutuksen tutkimuslaitos.

Zilliacus, H. (2014), Supporting student's identities and inclusion in minority religious and secular ethics education: A studty on plurality in the Finnish comprehensive school, Helsinki: University of Helsinki. 